\title{
Miłość pasterska jako rdzeń tożsamości kapłana i odpowiedź na współczesne wyzwania według Pastores dabo vobis
}

\begin{abstract}
E un onore partecipare alla Conferenza Internazionale su "San Giovanni Paolo II, che ha cambiato il volto del mondo", a quarant'anni dalla sua elevazione al Sommo Pontifcato. Ringrazio il Pastore di questa Arcidiocesi, S.E. Mons Marek Jedraszewski, per il fraterno invito, S.Em il Card. Stanislaw Dziwisz, e tutti i presenti.

Mi sono state chieste alcune considerazioni sul ruolo del Sacerdote nel mondo contemporaneo alla luce dell'Esortazione Apostolica "Pastores dabo vobis", con particolare riferimento ad alcuni numeri del Documento. Riconosco che - quanto più leggo l'Esortazione - tanto meglio ne vedo l'urgenza.
\end{abstract}

\section{Attualità dell'Esortazione Apostolica}

Proprio da qui desidero partire. Perché - dopo 26 anni - il Documento mantiene la sua attualità? Non è forse cambiato il mondo? La pastorale non richiede un'altra figura di prete? La mia risposta è semplice: quanto più il mondo sta cambiando, tanto più dobbiamo guardare a Cristo. Le mutazioni nel modo di pensare, di sentire e di vivere, investono e travolgono tutto; vogliono modificare anche l'identità sacerdotale ed ecclesiale: si cerca di ridurre la 
Chiesa ad una ONLUS e i sacerdoti ad operatori sociali. Lo scopo di questa operazione non è nascosto, almeno nei Paesi occidentali dove da anni si sostiene questa idea: voi Pastori siete esperti nella solidarietà umana, dedicatevi a questa sulla quale tutti siamo d'accordo, ma non occupatevi del modo di pensare della gente e dei suoi comportamenti. In sintesi: fate la carità, ma non parlate di verità. Se noi uniformassimo il nostro ministero in questa direzione, so per certo che molti ci coprirebbero d'oro! E' evidente che, se la Chiesa tace, altri possono parlare più agevolmente per condizionare la cultura, con l'intento di destrutturare l'umanità dell'uomo, di renderlo smarrito e fragile, quindi più esposto alle manipolazioni. Mi sembra che si potrebbe riassumere così: seminare confusione per disorientare l'uomo e riorientarlo ai fini di chi ha interessi di economia e di potere; sciogliere l'uomo per manovrarlo, farne una "cosa" di cui disporre.

\section{II secolarismo e la questione della fede}

Parlando di speranze e di ostacoli nell'annuncio del Vangelo, Giovanni Paolo II scrive che "cadono pregiudizi ideologici e chiusure violente all'annuncio dei valori spirituali e religiosi, mentre sorgono nuove e insperate possibilità per l'evangelizzazione e la ripresa della vita ecclesiale in molte parti del mondo" (Pastores dabo vobis 6). A distanza di tempo, ci chiediamo quale sia la situazione oggi, se corrisponda ancora a questa lettura. A me pare di sì, ma con una considerazione complessiva. Il nostro tempo è segnato dal secolarismo che il documento descrive in modo incisivo affermando che oggi "la vita - anche nei suoi momenti più significativi e nelle sue scelte più decisive - viene vissuta come se Dio non esistesse" (ivi 8). A distanza di 26 anni, il secolarismo è ulteriormente dilagato e - come una nube tossica - assedia e si infiltra ovunque, cambiando l'alfabeto dell'umano.

Il secolarismo è una forma molto raffinata di quellateismo pratico di cui parlava già allora il Santo Pontefice: "Non cè più bisogno di combattere Dio, si pensa di poter fare semplicemente a meno di Lui" (ivi 7). Con altre parole Cornelio Fabro diceva: "se Dio cè, non c'entra"!

La questione centrale oggi, nel nostro occidente, è dunque la questione della fede: oggi più ancora di ieri. Se la fede langue la vita cristiana diventa moralismo sterile e pesante, e la Chiesa perde se stéssa, si riduce ad altro, ad una burocrazia filantropica. E' questa la ragione per cui il cristianesimo è sfidato sulla fede: si vuole portare il Vangelo sul piano dell' umanismo senza la 
vita della grazia. Per questo - tra i molti compiti della pastorale - quello della fede è il più decisivo. Infatti, "Lesistenza cristiana - leggiamo - è vita spirituale, ossia vita animata e guidata dallo Spirito verso la santità o perfezione della carità" (ivi 19).

Mi viene alla mente l'inquietante domanda di Gesù: "Quando il Figlio dell'uomo tornerà sulla terra, troverà ancora la fede?” $(L c$ 18, 8). Cari Amici, è una domanda cruda e diretta che non ammette distrazioni. Cristo ci interroga perché non dobbiamo essere superficiali, ma neppure complicare i proble$\mathrm{mi}$. Ci vuole ricordare una verità teologica e pastorale: ogni pastorale o trova il suo fondamento nella dottrina oppure segue le suggestioni del momento. La Chiesa, infatti, cresce dall'interno verso l'esterno, non viceversa: e ciò richiama il primato dell'unione con Cristo. La fede ha al centro Gesù Cristo, e se la Chiesa si allontanasse da Cristo, gli uomini si allontanerebbero da lei! Mi sembra questo il primo messaggio che la domanda di Gesù dona a noi. Ma ne contiene altri due. Il primo è che la fede non può estinguersi sulla terra, poiché Gesù è risorto, e il Suo Spirito è all'opera. Il secondo è che la fede può indebolirsi e ridursi a minoranza in alcuni punti della terra, ma si accende e cresce in altri. Le comunità cristiane possono ammalarsi, ma possono anche guarire. Possono diventare anemiche fino alla irrilevanza, ma altrove prendono vigore e si espandono. Ecco perché alla domanda del Maestro possiamo rispondere: sì, alla fine del mondo la fede ci sarà ancora!

\section{Sotto la superficie, la vita}

Ma, mi chiedo, il nostro popolo è davvero convertito a questa mentalità? Vive secondo questa forma di totalitarismo ideologico in veste di liberazione e di umanesimo adulto? Mi sembra innegabile - nonostante la massiccia propaganda secolarista - che la vita si svolga ancora con criteri cristiani o vicini al Vangelo. E' noto che la schiuma del mare porta alla luce il peggio, ma non è tutto il mare: sotto la superficie della cronaca, della cultura di moda e dei maestri di turno, la vita brulica: come pastori conosciamo la vita sana di tanta gente che vive con semplicità ed eroismo la vita quotidiana, gli affetti, la famiglia, l'educazione dei figli, la cura dei malati e degli anziani; vive con serietà il lavoro, cammina a testa alta non per presunzione ma per onestà. Nel fondo del cuore umano abita una nostalgia di Infinito; per questo possiamo dire che il migliore alleato del Vangelo non sono l'organizzazione, le risorse, la cultura dominante, l'appoggio politico, ma l'uomo. E per tale ragione non possiamo 
disperare mai. Non sappiamo quanto durerà la metamorfosi antropologica in atto, né fin dove giungerà, ma è certo che quel senso di incompletezza che ogni uomo avverte in se stesso non potrà mai morire né essere ucciso.

\section{L'identità sacerdotale}

La tentazione può essere quella di rincorrere il mondo nel tentativo di convertirlo, ma il risultato di questa ingenuità è quello di essere noi ad adeguarci alla mentalità secolare: si può ottenere plauso per noi, ma non fede nel Signore. Quanto più la cultura è cangiante, tanto più dobbiamo guardare a Gesù, poiché quello che siamo lo troviamo in Lui non altrove: l'identità sacerdotale, infatti, è una realtà relativa, cioè in relazione a Cristo Buon Pastore, non ad altro. Lo vediamo nel Vangelo: i Dodici diventano Pastori non solo perché sono chiamati dal Maestro, ma perché guardano a Lui che è il grande Pastore. Gesù - dopo una notte di preghiera - sceglie dodici uomini "perché stessero con Lui": li invita a dimorare con Lui, ad entrare nell'intimità della sua amicizia, a prendere parte al Suo mondo interiore; li chiama uno ad uno e li invita ad arrendersi al suo amore. Il testo evangelico prosegue: "E anche per mandarli a predicare" (Mc 3, 14-15). Quella piccola parola "anche" segna una priorità decisiva tra "lo stare" e "l'andare".

\section{Stare per poter andare}

Vorrei fare due considerazioni su questo punto.

1) Innanzitutto lo stare con Gesù non è solamente una scuola di pastorale - un imparare dei principi, delle verità, dei criteri - ma è anche un "prendere forma" interiore. Si può dire che Gesù, mentre li chiama a stare con Lui, li plasma nella loro umanità come - in un certo senso - l'artista plasma la creta. In quest'opera di formazione anche Gesù deve fare i conti con la libertà e le peculiarità di ogni apostolo. La storia è nota. Ma, in questo dimorare con il Maestro, nel lasciarsi lavorare da Lui, essi diventano simili a Gesù nel modo di pensare, di sentire il mondo, di agire: diventano "immagine viva e trasparente di Cristo sacerdote" (ivi 12). Ma, ad un certo momento, il rapporto con Gesù si invera a tal punto da toccare non più solo la somiglianza, ma l'essere 
dell' uomo, diventa un "legame ontologico specifico che unisce il sacerdote a Cristo, sommo sacerdote e buon pastore" (id 11), così da poter agire efficacemente nella sua persona. Risiede qui l'identità sacerdotale: tenere ferma e chiara l'identità che Cristo ci ha dato è la prima risposta alle sfide contemporanee. In un clima di programmata confusione, il primo modo per starci in mezzo in modo costruttivo è sapere quello che si è. A volte si ritiene che riconoscere la propria identità sia segno di arroganza e di distacco, mentre invece condividere la confusione esprime vicinanza. Si sente dire che noi abbiamo la pretesa di possedere la verità, invero è la verità che possiede noi, e ci chiede di esserle fedeli nonostante le nostre debolezze.

2) Una seconda considerazione è questa: stare con Gesù è la condizione per andare a predicare. Nella mentalità segnata dall'efficienza, è facile che anche la pastorale sia vista come produzione di risultati, mettendo in secondo piano il fondamento e l'anima dell'apostolato. Un episodio evangelico significativo è la visita di Gesù nella casa di Lazzaro: il Maestro non rimprovera Marta perché lavora per dargli la migliore ospitalità, né rimprovera Maria perché non aiuta Marta nei necessari lavori. Tiene insieme le due situazioni, ma ne indica l'ordine intrinseco e dinamico: se - come scrive san Giacomo - "la fede senza le opere è morta" $(G c 2,20)$ il pastore deve ricordare che la preghiera è la prima opera, e - nello stesso tempo - è principio e garanzia di ogni altra opera. La contemplazione e l'azione non si contrappongono, ma si richiamano: la contemplazione è fondamento dell'azione, e l'azione invera la nostra preghiera. Il criterio può suonare un po' freddo e meccanico ma, in realtà, risponde alla dinamica che San Giovanni Paolo II riassume in modo efficace quando afferma che la vocazione sacerdotale è una "dichiarazione d'amore". Tutti sappiamo che l'amore dichiarato contiene la richiesta d'essere ricambiato con l'amore.

\section{La vocazione sacerdotale come "dichiarazione d'amore"}

Qui entriamo in un punto non solo decisivo, ma anche delicato e urgente. Perché? Che sia decisivo è evidente: "Dio ha tanto amato il mondo da dare il suo Figlio unigenito" $(G v$ 3, 16). Siamo nel cuore della fede cristiana: Gesù Cristo, Verbo incarnato, Salvatore del mondo, Pontefice per la vita eterna. Nel mistero della sua croce, Dio si volge contro se stesso per donarsi all'uomo e salvarlo. Egli rivela all'uomo il suo Principio e il suo Destino, l'Origine e il Fine; 
gli dona così un nuovo orizzonte, e con ciò la direzione essenziale del cammino. Ma la questione della vocazione come "dichiarazione d'amore" mi sembra anche delicata e urgente per due ragioni.

1) In primo luogo, perché mi pare ci sia il rischio che si facciano avanti motivazioni proprie del mondo secolare: la realizzazione dei propri talenti, la soddisfazione delle aspirazioni personali, la selezione dei compiti preferiti, una sensibilità impiegatizia del tempo... Nella misura in cui questo è vero, si falsa l'itinerario formativo, ma soprattutto si vive il sacerdozio con prospettive sbagliate che creano distorsioni interiori e uno scontento ingiusto e pericoloso per il Pastore, il Presbiterio, la comunità cristiana. Anche il rapporto con i Confratelli e con il Vescovo - rapporto nel quale siamo costituiti presbiteri - ne risente, anziché aiutare ed essere aiutati si accrescono le fatiche interiori. In questa situazione, il servizio pastorale può essere anche intenso ma non è efficace, e soprattutto diventa sempre più stancante per il sacerdote: certe stanchezze pastorali non sono in realtà fisiche ma spirituali. E' una questione di amore: se la vocazione è una dichiarazione d'amore, allora o la risposta è quella del nostro amore oppure tutto entra in una prospettiva diversa: solo l'amore, però, può animare la vita. E' necessario pertanto sempre "ravvivare il dono" che è in noi.

2) Vorrei aggiungere una seconda ragione: proprio perché la vocazione sacerdotale è una questione d'amore radicale, oggi si aggiunge una difficoltà che si respira nell'aria e che riguarda l'idea stessa dell'amore. Si pensa che l'amore sia emozione e sentimento: questi sono certamente elementi dell' amore, ma non lo qualificano nella sua sostanza. Lamore - nelle sue diverse forme - non cerca se stesso, ma il bene dell'altro, diventa rinuncia ed è pronto al sacrificio: è dono di sé a prescindere dalla corrispondenza e dalla gratificazione propria. Mi sembra che la cultura induca a concepire lamore in termini di gratificazione personale creando così difficoltà serie verso ciò che nel ministero pastorale non è gratificante. Si registra a volte una fragile resistenza rispetto a conflitti, incomprensioni, tensioni e delusioni che la vita in generale comporta. Anche l'insofferenza nei rapporti, a volte la fatica a perdonare gli altri - confratelli o laici - a dare fiducia, la facilità a ritenerci offesi per poco, a vivere nel ricordo di torti veri o presunti, o altro ancora, mostrano una umanità fragile sulla quale la preghiera non sempre incide in profondità. A mio parere, oltre che la necessità di una vita spirituale più profonda, è necessario rivedere quanto la dimensione dell' amore sia radicata nello spirito, nella psiche e nel corpo. 


\section{La carità pastorale}

Emerge qui "l'amoris officium", la "carità pastorale", che costituisce un elemento portante del Documento: "la vita spirituale del sacerdote viene improntata, plasmata, connotata da quegli atteggiamenti e comportamenti che sono propri di Gesù Cristo capo e pastore della Chiesa e che si compendiano nella sua carità pastorale" (ivi 21). Il Santo Pontefice spiega: "Il contenuto essenziale della carità pastorale è il dono di sé, il totale dono di sé alla Chiesa [...] Non è soltanto quello che facciamo, ma il dono di noi stessi che mostra l'amore di Cristo per il suo gregge" (ivi 23). Il sacerdote - costituito sacramentalmente capo e pastore - sa che guidare un popolo significa non spadroneggiare ma amare. Alcune considerazioni.

1) La vita spirituale del sacerdote è legata alla sua azione pastorale, come nel matrimonio è legata alla vita coniugale e familiare: "Ogni sacerdote [...] fruisce di una grazia speciale in virtù della quale, mentre è al servizio della gente che gli è affidata e di tutto il popolo di Dio, egli può avvicinarsi più efficacemente alla perfezione di Colui del quale è rappresentante" (ivi 20). La coscienza della forza santificante e unificante del nostro ministero è da ricordare con crescente convinzione, affinché i doveri pastorali non siano visti come qualcosa di alternativo o addirittura di contrapposto al nostro cammino spirituale.

2) Dobbiamo avere coscienza che il primo atto della carità pastorale del pastore non è fare qualcosa per le anime, ma è lasciarsi fare da Dio, cioè è lasciarsi amare da Lui. Sarà possibile e vero l'amore per gli altri nel ministero nella misura in cui noi ci arrendiamo al Signore, cioè ci lasciamo amare.

3) Non è criterio di carità pastorale il consenso degli altri, bensì la fedeltà al deposito della fede custodito dalla Chiesa. La verità di Dio è amore, e l'amore è volere il bene dell'altro. Il bene di ognuno è corrispondere al disegno di Dio, a come il Creatore lo ha pensato: è questa la verità di ciascuno e in questo sta l'amore del Padre. Il Logos fatto carne ha rivelato la verità di Dio e la verità dell' uomo: "tutte le cose sono state create per mezzo di Lui e in vista di Lui" $(\mathrm{Col} 1,16)$. Temere di indicare l'altezza a cui il Signore ci ha portati e la meta della santità e della beatitudine eterna, tacere la verità, non è carità pastorale in nessuna circostanza storica e culturale. Già l'Apostolo l'aveva detto: "Verrà giorno in cui non si sopporterà più la sana dottrina, ma, per il prurito di udire qualcosa, gli uomini si circonderanno di maestri secondo le proprie voglie, 
rifiutando di dare ascolto alla verità per volgersi alle favole" $(2 \operatorname{Tm} 4,3-4)$. La redenzione - possiamo dire - nel senso pieno consiste nel fatto che la verità diventi riconoscibile, e ciò è possibile solo se Dio diventa riconoscibile: Egli lo è diventato in Gesù.

4) Il nostro tempo richiede un particolare atto di amore pastorale: suscitare le domande più radicali che - come si è detto - possono dormire ma non morire nella coscienza. La verità funzionale sull'uomo (come funzioni) è diventata visibile, ma la verità su lui stesso - su chi egli sia, da dove venga, per quale scopo esista, che cosa sia il bene o il male - questa è unaltra cosa. E di questa verità l'uomo è continuo cercatore anche quando non la cerca espressamente perché svogliato e distratto.

5) La carità pastorale richiede anche di rispettare noi stessi: Questo atto di rispetto si attua nel riconoscere ciò che Gesù ha fatto di noi, "strumenti vivi di Cristo eterno sacerdote" (Pastores dabo vobis, 20). Quando, in nome dell' incontro e della vicinanza, di fatto si abdica a questa straordinaria realtà e ci si adegua alla mentalità del secolo, potremo forse suscitare qualche simpatia umana, ma bisogna ricordare che lo scopo è avvicinare a Dio: "il sacerdote è l'uomo di Dio, colui che appartiene a Dio e fa pensare a Dio" (ivi 47). Tutto di sé, la fede, le virtù umane e cristiane, sono finalizzate ad aprire alle anime la via di Dio. Anche l'indispensabile capacità di relazione e di collaborazione non ha come scopo lo stare bene insieme, ma facilitare laccesso al Signore, alla sua Persona, al suo modo di vedere l'esistenza, di giudicare e di vivere. Il sacerdote - stando con la gente - sa che lo scopo vero è quello di far incontrare Gesù, di evocare la nostalgia per un mondo altro che - pur essendo invisibile - non nega il mondo sensibile, bensì lo abbraccia e lo eleva. Un mondo non abitato da numi da temere e da propiziarsi, ma da Dio che è Trinità, dalla Madonna e dai Santi, dagli angeli e dalle anime beate. E' una compagnia che cammina con noi, che ci sostiene, che ci attende per la gioia eterna. Le chiese, le cappelle, le edicole, le immagini della nostra fede, fanno sentire che l'uomo non è solo nel pellegrinaggio terreno; è dentro a un grande fiume, ad un popolo che inizia nel tempo e si compie nel cielo.

6) La carità pastorale è "lasciarsi afferrare, quasi mangiare, dalle necessità e dalle esigenze del gregge. Queste ultime devono avere una giusta razionalità, e talvolta vanno selezionate e sottoposte a verifica" (ivi 28). Le parole di San Giovanni Paolo II sono quanto mai puntuali: la carità non deve spingere il pastore a sciogliere se stesso negli altri, nei loro dubbi, nelle loro ombre, nel- 
la emotività esasperata, nel mondo fluttuante dei sentimenti, nei sofismi della ragione. Se così fosse, il pastore non potrebbe servire le anime, resterebbe impigliato: sarebbe come il sale che perde il sapore.

\section{II roveto ardente e il cenacolo}

Un'ultima parola. La carità pastorale chiama in causa la maturità affettiva: "Nella verginità e nel celibato la castità mantiene il suo significato originario, quello cioè di una sessualità umana vissuta come autentica manifestazione e prezioso servizio allamore di comunione e di donazione interpersonale" (ivi 29). Prima che un richiamo alla necessaria e serena vigilanza sui cancelli del cuore, è opportuno porre l'attenzione sulla vita spirituale del pastore: essa è qualificata certamente dal servizio pastorale, ma sempre a partire da quello "stare con Lui" che sigilla la chiamata dei Dodici. Il criterio più decisivo della nostra vita sacerdotale non è ciò che facciamo, ma ciò che siamo e quindi come facciamo i nostri doveri. Si può esprimere semplicemente così: sono contento di essere sacerdote? Sento la grandezza di ciò che Gesù ha fatto di me con l'ordinazione? Sono cosciente che la vicinanza umana alla gente non basta se non avvicina la anime a Dio? Il mio volto, le parole, le azioni pastorali, i comportamenti privati irradiano questa gioia? Se - nonostante le fatiche quotidiane - non viviamo la gioia di fondo, diventiamo introversi, malinconici, risentiti: idealizziamo situazioni di altri e ci allontaniamo dalla realtà. Facilmente allora si cercano compensazioni illusorie, ci si isola dal presbiterio, dalla vita diocesana, giudicando tutto in modo opaco e sfiduciato, ritenendo ogni iniziativa inutile, poco interessante, non rispondente alle proprie preferenze.

Senza il calore interiore il cuore umano non può vivere. Vale anche per i Pastori! E' necessaria una continua conversione a Dio così come ci è venuto incontro in Cristo: è questo il cuore di ogni rinnovamento, non le strutture, le organizzazioni, i programmi. Il primato di Dio non è assicurato né dal credere in Lui se non si vive "di" Lui, cioè se non si vive continuamente riferiti a Lui; né è assicurato dal lavorare per Dio se non si lavora "con" Lui. Le opere di Dio, infatti, possono farci dimenticare il suo volto: per amare veramente gli altri e servirli, dobbiamo lasciarci amare da Gesù, altrimenti rischiamo di amare negli altri noi stessi, di cercare l’appagamento, di attaccarci a chi ci è grato e ci gratifica.

La nostra vita spirituale è innanzitutto un continuo consegnarci - come Gesù sulla croce - al Padre e alla sua volontà; è fare spazio alla grazia che ci 
trasforma in creature nuove, che dona un cuore di carne. Fuori da questo orizzonte, si entra nella logica cripto-pelagiana diffusa, per cui, in fondo, ci salviamo da soli con la nostra buona volontà. Ma così tocchiamo la nostra disperante insufficienza nella via del bene, il cuore si trova solo con se stesso, in un gelo interiore dove è difficile vivere: si andrà alla ricerca del tepore di fuochi fatui.

Si ritorna alla semplice parola di Gesù: "Ne scelse dodici che stessero con Lui". Se il sacerdote non sta con il Maestro non andrà da nessuna parte, perché porterà solo se stesso; ma le anime non aspettano noi con le nostro doti, ma la grande Speranza, il grande Bene, la grande Gioia. Lo stare con Lui significa la messa quotidiana, la liturgia delle ore, il Rosario, la meditazione e così via. Ma ciò non basta. Poiché la vocazione è una "dichiarazione d'amore", e come tale chiede anche intimità, solitudine, cuore a cuore. Un' immagine significativa è il "roveto ardente" davanti al quale Mosè, a piedi scalzi, sosta in solitudine e si lascia trasformare. Mi pare che il punto più delicato stia qui. Intimismo? La dimensione personale non esclude quella comunitaria ma la sostanzia, così come quella comunitaria invera la preghiera personale.

La fraternità sacerdotale è necessaria anche per la maturità affettiva di cui parla l'Esortazione, una fraternità che si manifesta nelle forme concrete dell'esistenza e del ministero, ma che ancor prima deve alimentare l'umanità, la fede, la gioia della vocazione. Deve essere una fraternità matura: bisogna, infatti, saper stare soli per poter stare con gli altri e viceversa. Lincontro con i confratelli deve essere motivato non dalle cose da fare, ma da ciò che Gesù ha fatto e continua a fare di ciascuno, della sua vita e dell'apostolato. L'incontro e lamicizia presbiterale devono innanzitutto aiutare a scorgere la presenza del Risorto per insieme lodarlo, e affidare a Lui il frutto del ministero, contenti di lavorare nella sua vigna. Allora ogni incontro sarà un "cenacolo" dove il calore della fraternità sarà di stimolo e forza.

Cari Confratelli e cari Amici, il secolarismo - forma raffinata di totalitarismo - si presenta come il "nuovo mondo", una specie di età dell'oro, una terra promessa finalmente raggiunta, che porta un'umanità moderna, emancipata, soddisfatta. Per contro, il cristianesimo è presentato come il "mondo vecchio". Il cuore dell'uomo però sente nostalgia di qualcosa di diverso, di più alto e nobile: emerge qui la novità del Vangelo di cui abbiamo la grazia di essere ministri. Per questo possiamo dire a ragione che i sacerdoti non sono gli uomini del passato, ma i pastori del futuro, e che le comunità cristiane, con le loro difficoltà, non sono il tramonto, ma la promettente luce dell'alba. Grazie. 
To dla mnie zaszczyt uczestniczyć w Międzynarodowej Konferencji „Jan Paweł II, który zmienił oblicze świata”, 40 lat od jego wyboru na Stolicę Piotrową. Dziękuję Pasterzowi tej archidiecezji, JE Arcybiskupowi Markowi Jędraszewskiemu za braterskie zaproszenie, JE Kardynałowi Stanisławowi Dziwiszowi oraz wszystkim tu obecnym.

Poproszono mnie o podjęcie tematu roli kapłana we współczesnym świecie, w świetle adhortacji apostolskiej Pastores dabo vobis, ze szczególnym uwzględnieniem kilku punktów tegoż dokumentu. Przyznaję, że im dłużej wczytuję się w tę adhortację, tym wyraźniej widzę pilną potrzebę takich rozważań.

\section{Aktualność adhortacji apostolskiej Pastores dabo vobis}

Pragnę rozpocząć właśnie od tego: dlaczego - po 26 latach - dokument ten jest wciąż aktualny? Czyżby świat się nie zmienił? Czy duszpasterstwo nie potrzebuje innej postaci księdza? Odpowiadam prosto: im bardziej świat się zmienia, tym bardziej musimy wpatrywać się w Chrystusa. Zmiany myślenia, odczuwania i życia w świecie dotykają wszystkiego i dokonują przewrotu we wszystkim. Chcą objąć nawet tożsamość kapłana i Kościoła, próbuje się zredukować Kościół do jakiejś organizacji pożytku publicznego, a kapłanów - do pracowników socjalnych. Nie kryje się celu tego rodzaju operacji, przynajmniej w krajach zachodnich, gdzie od lat wyznaje się następującą ideę: wy, pasterze, jesteście ekspertami od ludzkiej solidarności, więc zajmijcie się tym, co do czego wszyscy jesteśmy zgodni, a nie tym, w jaki sposób myślą i zachowują się ludzie. Krótko mówiąc, zajmijcie się dobroczynnością, ale nie mówcie o prawdzie. Gdybyśmy dostosowali naszą posługę do takich postulatów, wiem na pewno, że wielu by nas ozłociło! Jasne jest, że jeśli Kościół milczy, inni mogą łatwiej wpływać na kulturowe uwarunkowania, z intencją rozbicia człowieczeństwa człowieka, uczynienia go zagubionym i kruchym, a zatem bardziej podatnym na manipulacje. Wydaje mi się, że można by to streścić następująco: sianie zamętu, aby zdezorientować człowieka i ukierunkować go na działania mające na celu interesy gospodarki i władzy; „rozmontowanie” człowieka, by posłużyć się nim po swojemu, zrobić z niego „coś”, czym można dysponować. 


\section{wian \\ 2. Sekularyzm a kwestia wiary}

Mówiąc o nadziejach i przeszkodach w głoszeniu Ewangelii, Jan Paweł II pisze, że „zanikają uprzedzenia ideologiczne i gwałtowne sprzeciwy wobec głoszenia wartości duchowych i religijnych, a pojawiają się nowe i nieoczekiwane możliwości ewangelizacji i rozwoju życia kościelnego w wielu częściach świata" ${ }^{2}$. Z perspektywy czasu zadajemy sobie pytanie, jaka jest dzisiaj sytuacja i czy odpowiada jeszcze tamtemu odczytaniu. Mnie się wydaje, że tak, ale wymaga to całościowego potraktowania. Nasze czasy naznaczone są przez sekularyzm, jaki cytowany dokument opisuje za pomocą ostrego sformułowania, stwierdzając, że dzisiaj żyje się „w taki sposób, również w chwilach bardzo ważnych i decydujących, jak gdyby Bóg nie istniał" ${ }^{53} .26$ lat od tamtego stwierdzenia sekularyzm rozlał się jeszcze bardziej i - niczym toksyczna chmura - osiada i przenika wszędzie, zmieniając alfabet ludzkiego języka.

Sekularyzm to bardzo wyrafinowana forma ateizmu praktycznego, o którym już wówczas mówił święty papież: „Nie potrzeba już zwalczać Boga - człowiek myśli, że może się po prostu bez Niego obejść" ${ }^{44}$. Cornelio Fabro ujął to inaczej: „Jeśli Bóg jest, to nie ma z tym nic wspólnego!”.

Dzisiaj centralną kwestią na naszym Zachodzie jest więc kwestia wiary: dzisiaj jeszcze bardziej niż w przeszłości. Jeżeli wiara słabnie, chrześcijańskie życie staje się niepłodnym i ciążącym moralizmem, a Kościół sam siebie zatraca, zamienia się w coś innego, w filantropijną biurokrację. To z tego powodu wiara jest dla chrześcijaństwa wyzwaniem: chce się przenieść Ewangelię na pole humanizmu, gdzie nie ma miejsca na życie łaską. Dlatego - pośród wielu zadań duszpasterstwa - zadanie dotyczące wiary jest najbardziej decydujące. Rzeczywiście bowiem „życie chrześcijańskie jest «życiem duchowym», czyli życiem ożywianym i kierowanym przez Ducha ku świętości i ku doskonaleniu miłości" ${ }^{55}$.

Przychodzi mi na myśl nurtujące pytanie Jezusa: „Czy jednak Syn Człowieczy znajdzie wiarę na ziemi, gdy przyjdzie?” (Łk 18, 8). Drodzy Przyjaciele, na tym surowym i bezpośrednim pytaniu trzeba się skupić. Chrystus pyta

\footnotetext{
52 Jan Paweł II, Adhortacja apostolska Pastores dabo vobis, Watykan 1992, nr 6.

53 Jan Paweł II, Pastores dabo vobis..., dz. cyt., nr 8.

$54 \quad$ Jan Paweł II, Pastores dabo vobis..., dz. cyt., nr 7.

55 Jan Paweł II, Pastores dabo vobis..., dz. cyt., nr 19.
} 
nas o to, bo nie możemy być powierzchowni, ale też nie możemy komplikować problemów. Trzeba przypomnieć teologiczną i duszpasterską prawdę: każde duszpasterstwo albo znajdzie swój fundament w doktrynie, albo pójdzie za sugestiami chwili. Kościół bowiem rośnie z wewnątrz na zewnątrz, nie odwrotnie, a to wymaga dania pierwszeństwa zjednoczeniu z Chrystusem. W centrum wiary stoi Jezus Chrystus. Jeśli Kościół by się od Niego oddalił, ludzie oddaliliby się od Kościoła! Wydaje mi się, że jest to pierwsze przesłanie, jakie daje nam owo pytanie Jezusa. Ale niesie jeszcze dwa inne. Po pierwsze: wiara nie może się na ziemi wypalić, ponieważ Jezus zmartwychwstał, a Jego Duch działa. Po drugie: wiara może osłabnąć i stać się udziałem mniejszości w niektórych miejscach na ziemi, ale rozpala się i rośnie w innych. Wspólnoty chrześcijańskie mogą zachorować, lecz mogą też doznać uzdrowienia. Mogą stać się anemiczne, aż do utraty znaczenia, lecz gdzie indziej rosną w siłę i się rozprzestrzeniają. Oto dlaczego możemy odpowiedzieć na pytanie Mistrza: tak, przy końcu świata wiara nadal będzie trwać!

\section{Pod powierzchnią - życie}

Jednak, pytam się, czy nasz lud naprawdę nawrócił się na tę mentalność? Czy żyje wedle tej formy totalitaryzmu ideologicznego pod przykrywką wyzwolenia i dojrzałego humanizmu? Wydaje mi się niezaprzeczalnym - pomimo masowej, sekularnej propagandy - że życie nadal się toczy zgodnie z kryteriami chrześcijańskimi lub bliskimi Ewangelii. Wiadomo, że piana morska wyrzuca na wierzch to, co najgorsze, ale nie wszystko to jest morzem. Pod powierzchnią bulwersujących wydarzeń, modnej kultury i dyżurnych mistrzów, pulsuje życie. Jako duszpasterze znamy zdrowe życie wielu ludzi prosto i heroicznie przeżywających codzienność, miłość, życie rodzinne, wychowanie dzieci, opiekę nad chorymi i starszymi, poważnie traktujących pracę, kroczących z podniesioną głową nie z powodu zarozumiałości, lecz dzięki uczciwości. $\mathrm{Na}$ dnie ludzkiego serca mieszka tęsknota za nieskończonością. Dlatego możemy powiedzieć, że najlepszym sprzymierzeńcem Ewangelii nie jest organizacja, zasoby, dominująca kultura, poparcie polityczne, ale człowiek. I z tego powodu nigdy nie wolno nam popaść w desperację. Nie wiemy, jak długo potrwa dziejąca się teraz antropologiczna przemiana, ani jak daleko sięgnie, ale pewne jest, że owo poczucie niekompletności, jakie każdy człowiek nosi w sobie, nigdy nie będzie mogło umrzeć, ani zostać zabite. 


\section{Kapłańska tożsamość}

Może pojawić się pokusa, by gonić za światem, próbując go nawrócić, ale rezultatem takiej naiwności jest nasze dostosowanie się do świeckiej mentalności. Można zdobyć poklask dla siebie, nie zdobywszy nowych wierzących w Pana. Im bardziej kultura przybiera nowe odcienie, tym bardziej musimy patrzeć na Jezusa, gdyż to, kim jesteśmy, odnajdujemy w Nim, nie gdzie indziej. Bowiem kapłańska tożsamość jest rzeczywistością relacyjną, to znaczy w relacji z Chrystusem, Dobrym Pasterzem, nie z kimś innym. Widzimy to w Ewangelii: Dwunastu staje się pasterzami nie tylko dlatego, że Mistrz ich powołał, lecz dlatego, że patrzą na Niego, wielkiego Pasterza. Jezus - po nocy spędzonej na modlitwie - wybiera dwunastu mężczyzn, „aby Mu towarzyszyli”. Zaprasza ich, aby z Nim mieszkali, by weszli z Nim w intymną przyjaźń, by mieli udział w Jego wewnętrznym świecie. Powołuje ich jednego po drugim i zaprasza, aby poddali się Jego miłości. Dalej w Ewangelii czytamy: „[a także] by mógł wysyłać ich na głoszenie nauki” (Mk 3, 14). To małe słówko „także” ${ }^{56}$ wyznacza decydujące pierwszeństwo „towarzyszenia Mu”, przebywania z Nim, przed „pójściem”, wyruszeniem w drogę bez Niego.

\section{Przebywać, aby móc pójść}

Chciałbym zwrócić uwagę na dwie sprawy:

1) Przede wszystkim - przebywanie z Jezusem nie jest jedynie szkołą duszpasterstwa - uczeniem się zasad, prawd, kryteriów, ale jest również wewnętrznym „kształtowaniem”. Można powiedzieć, że Jezus, kiedy ich przyzywa, żeby z Nim przebywali, formuje ich w ich człowieczeństwie, tak jak w pewnym sensie - artysta formuje glinę. Podczas takiego dzieła tworzenia nawet Jezus musi liczyć się z wolnością i specyfiką każdego apostoła. Znamy tę historię. Jednak poprzez zamieszkiwanie z Mistrzem, przez pozwolenie, aby nad nimi pracował, stają się oni podobni do Jezusa w sposobie myślenia, odbierania świata i działania. Stają się „żywym i przejrzystym obrazem Chrystusa Kapłana"s7. Lecz w pewnej chwili relacja z Jezusem staje się prawdziwa

\footnotetext{
${ }_{56}$ Słowo, którego nie ma w polskim tłumaczeniu ani w Biblii Tysiąclecia z Pallottinum, ani w najnowszym przekładzie, wydanym przez Edycję Świętego Pawła - [przyp. tłum.]

$57 \quad$ Jan Paweł II, Pastores dabo vobis..., dz. cyt., $\mathrm{nr} 12$.
} 
do tego stopnia, że dotyka już nie tylko podobieństwa, ale samego bytu człowieka, staje się „szczególnym związkiem ontologicznym, który jednoczy kapłana z Chrystusem, Najwyższym Kapłanem i Dobrym Pasterzem" ${ }^{58}$ tak, iż może skutecznie działać w swojej osobie. Na tym polega tożsamość kapłańska: utrzymanie niezmiennej i jasnej tożsamości, jaką nadał nam Chrystus, to pierwsza odpowiedź na współczesne wyzwania. W atmosferze programowego zamętu, pierwszym sposobem, żeby konstruktywnie w nim żyć, to wiedzieć, kim się jest. Czasami uważa się, jakoby podkreślanie własnej tożsamości miałoby być oznaką pychy i dystansowania się, podczas gdy udział w zamęcie miałby wyrażać bliskość. Można usłyszeć, że pretendujemy do roli tych, którzy posiedli prawdę, tymczasem to prawda posiadła nas i wymaga od nas, byśmy byli wierni pomimo naszych słabości.

2) Po drugie - przebywanie z Jezusem to warunek głoszenia. W mentalności naznaczonej koniecznością efektywności, łatwo o to, żeby także duszpasterstwo widziane było jako przestrzeń osiągania dobrych rezultatów, gdzie na drugi plan odsuwa się fundament i ducha apostolatu. Pewnym znaczącym epizodem w Ewangelii jest wizyta Jezusa w domu Łazarza. Mistrz nie upomina Marty za to, że krząta się, aby udzielić Mu jak najlepszej gościny, ani też nie upomina Marii za to, że nie pomaga Marcie w koniecznych pracach. Zestawiając razem te dwie sytuacje, wskazuje na ich właściwy i dynamiczny porządek. Jeśli - jak pisze św. Jakub - „wiara bez uczynków jest martwa” (por. Jk 2, 17. 20), to pasterz musi pamiętać, że modlitwa jest pierwszym działaniem, a jednocześnie jest początkiem i gwarancją każdego innego działania. Kontemplacja i działanie nie przeciwstawiają się sobie, ale wzajemnie się do siebie odwołują: kontemplacja jest podstawą działania, a działanie konkretyzuje naszą modlitwę. Może się wydawać, że to trochę chłodne i mechaniczne kryterium, lecz w rzeczywistości odpowiada dynamice, jaką Jan Paweł II umiejętnie streszcza, stwierdzając, że powołanie kapłańskie jest „wyznaniem miłości”. Wszyscy wiemy, że wyznana miłość prosi o wzajemność.

\section{Powołanie kapłańskie jako "Wyznanie miłości"}

Tutaj dochodzimy do punktu nie tylko decydującego, ale także delikatnego i naglącego. Dlaczego? To, że decydujący, to oczywiste: „Tak bowiem Bóg 
umiłował świat, że Syna swego Jednorodzonego dał" (J 3, 16). Jesteśmy w sercu chrześcijańskiej wiary: Jezus Chrystus, Słowo wcielone, Zbawiciel świata, Kapłan na życie wieczne. W tajemnicy Jego krzyża Bóg zwraca się przeciw samemu Sobie, aby oddać się człowiekowi i go zbawić. Objawia On człowiekowi Swoje Źródło i Swoje Przeznaczenie, Swój Początek i Swój Koniec. $\mathrm{W}$ ten sposób daje mu nowy horyzont, a wraz z tym, najważniejszy kierunek drogi. Jednak kwestia powołania jako „wyznania miłości” wydaje mi się również delikatna i nagląca $\mathrm{z}$ dwóch powodów.

1) Po pierwsze - zdaje mi się, iż istnieje ryzyko, że będziemy przyjmować motywacje właściwe dla świeckiego świata - realizację własnych talentów, zaspokojenie osobistych aspiracji, wybór preferowanych zadań, wrażliwość urzędnika na czas... W takiej mierze, w jakiej to się dokonuje, ścieżka formacyjna ulega zafałszowaniu, ale przede wszystkim kapłaństwo przeżywane jest w niewłaściwej perspektywie, tworzącej skrzywienia wewnętrzne oraz niewłaściwe niezadowolenie, niebezpieczne dla pasterza, prezbitera i chrześcijańskiej wspólnoty. Cierpi na tym również relacja ze współbraćmi i z biskupem - relacja, w której zostaliśmy ustanowieni prezbiterami - zamiast pomagać i otrzymywać pomoc, narastają w niej wewnętrzne trudności. W tej sytuacji służba duszpasterska, może nawet intensywna, nie jest owocna, a przede wszystkim staje się coraz bardziej męcząca dla kapłana; niektóre sytuacje rzeczywiście nie dotyczą fizycznego, lecz duchowego zmęczenia pasterza. To kwestia miłości: jeśli powołanie jest jej wyznaniem, wówczas albo nasza miłość odpowiada, albo wszystko nabiera innej perspektywy. Jednak tylko miłość może ożywić życie. Dlatego trzeba ciągle „rozpalać na nowo charyzmat”, który jest w nas (por. $2 \operatorname{Tm} 1,6$ ).

2) Chciałbym dodać drugi powód - właśnie dlatego, że powołanie kapłańskie jest sprawą radykalnej miłości, dzisiaj dochodzi trudność wyczuwalna w powietrzu, dotycząca samej idei miłości. Myśli się, że miłość to emocja i uczucie. Owszem, są one z pewnością elementami miłości, jednak nie stanowią o jej istocie. Miłość - w swych przeróżnych formach - nie szuka siebie, ale dobra drugiego, staje się rezygnacją i gotowa jest na poświęcenie: jest darem z siebie, niezależnie od tego, czy otrzyma wzajemność i zapłatę. Wydaje mi się, że kultura sprowadza pojęcie miłości do osobistej satysfakcji, tworząc w ten sposób poważne trudności w odniesieniu do tego, co w posłudze pasterskiej nie jest satysfakcjonujące. Obserwuje się czasem bardzo słabą odporność na konflikty, nieporozumienia, napięcia i rozczarowania, jakie życie ogólnie za sobą pociąga. Również niechęć w relacjach, czasami trudność 
z przebaczeniem innym - współbraciom czy świeckim, trudność z zaufaniem, łatwość obrażania się o byle co, rozpamiętywanie krzywd - prawdziwych lub domniemanych, czy inne jeszcze sprawy ukazują kruchą strukturę człowieka, na którą modlitwa nie zawsze ma głęboki wpływ. Moim zdaniem, oprócz konieczności pogłębienia życia duchowego, trzeba zbadać, na ile miłość zakorzeniona jest $\mathrm{w}$ duchu, w psyche i w ciele.

\section{Pasterska miłość}

Wyłania się tutaj amoris officium, „pasterska miłość”, stanowiąca element przewodni cytowanego dokumentu: „Życie duchowe kapłana zostaje naznaczone, ukształtowane i określone przez postawy i wzory postępowania znamionujące Jezusa Chrystusa Głowę i Pasterza Kościoła, które objawiają się w Jego pasterskiej miłości” ${ }^{9}$. Święty papież wyjaśnia dalej: „Miłość pasterska jest przede wszystkim darem z siebie, całkowitym darem z siebie dla Kościoła [...]. Nie tylko nasze czyny, ale nasz dar z siebie jest tym, co ukazuje miłość Chrystusa do Jego owczarni”" ${ }^{\prime 0}$. Kapłan - na mocy sakramentu ustanowiony głową i pasterzem - wie, że prowadzenie ludu nie znaczy rządzić się, ale kochać. Oto kilka myśli z tym związanych:

1) Życie duchowe kapłana związane jest z jego duszpasterskim działaniem, analogicznie jak w małżeństwie życie duchowe związane jest z życiem małżeńskim i rodzinnym: „Każdy kapłan [...] obdarzony jest też szczególną łaską, aby służąc powierzonym sobie ludziom i całemu Ludowi Bożemu, mógł skuteczniej dążyć do doskonałości Tego, którego reprezentuje" ${ }^{61}$. Z rosnącym przekonaniem należy przypominać o świadomości uświęcającej i jednoczącej siły naszej posługi, ażeby pasterskie obowiązki nie były widziane jako coś alternatywnego, czy wręcz przeciwstawnego naszej duchowej drodze.

2) Musimy mieć świadomość, że pierwszym aktem pasterskiej miłości kapłana nie jest uczynienie czegoś dla dusz, ale pozwolenie, by to Bóg działał, czyli pozwolenie, aby Bóg go kochał. Miłość do innych w naszej posłudze będzie

\footnotetext{
$59 \quad$ Jan Paweł II, Pastores dabo vobis..., dz. cyt., nr 21.

60 Jan Paweł II, Pastores dabo vobis..., dz. cyt., nr 23.

${ }_{61} \quad$ Jan Paweł II, Pastores dabo vobis..., dz. cyt., nr 20.
} 
możliwa i prawdziwa w takiej mierze, $w$ jakiej poddajemy się Panu, czyli pozwalamy Mu się kochać.

3) Kryterium pasterskiej miłości nie jest akceptacja ze strony innych, lecz wierność depozytowi wiary, strzeżonemu w Kościele. Prawda o Bogu to miłość, a miłość to pragnąć dobra dla drugiego człowieka. Dobrem każdego człowieka jest to, aby odpowiadał planowi Boga, temu, jakim go Stwórca wymyślił: taka jest prawda o każdym i na tym polega miłość Ojca. Wcielony Logos objawił prawdę o Bogu i prawdę o człowieku: „Wszystko przez Niego i dla Niego zostało stworzone" (Kol 1, 16). Obawa przed wskazywaniem wielkości, do jakiej Pan nas wyniósł oraz celu świętości i wiecznego szczęścia, przemilczanie prawdy - to nie jest miłość pasterska, w żadnych okolicznościach historycznych i kulturowych. Już Apostoł [Paweł] powiedział: „Przyjdzie bowiem chwila, kiedy zdrowej nauki nie będą znosili, ale według własnych pożądań - ponieważ ich uszy świerzbią - będą sobie mnożyli nauczycieli. Będą się odwracali od słuchania prawdy, a obrócą się ku zmyślonym opowiadaniom" (2 Tm 4, 3-4). Odkupienie - można powiedzieć - w pełnym sensie polega na tym, że prawda staje się rozpoznawalna, a to jest możliwe tylko wtedy, jeśli Bóg staje się rozpoznawalny: a stał się On takim w Jezusie.

4) Nasze czasy wymagają szczególnego aktu pasterskiej miłości: wzbudzania najbardziej radykalnych pytań, które - jak już zostało to powiedziane - mogą być uśpione w sumieniu, ale nie mogą zostać zabite. Funkcjonalna prawda o człowieku (to, jak funkcjonuje) stała się widzialna, jednak prawda o nim samym - o tym, kim on jest, skąd pochodzi, po co istnieje, co jest dobrem, a co złem - to inna sprawa. I tej prawdy człowiek nieustannie szuka, nawet wtedy, kiedy nie jest to zamierzone poszukiwanie, bo uległ zniechęceniu czy rozkojarzeniu.

5) Pasterska miłość wymaga również tego, byśmy sami siebie szanowali. Akt poszanowania siebie dokonuje się wtedy, kiedy uznajemy to, kim Jezus nas uczynił - „żywymi narzędziami Chrystusa, Wiecznego Kapłana” ${ }^{{ }^{2}}$. Kiedy, w imię spotkania i bliskości, tak naprawdę rezygnujemy z tej nadzwyczajnej rzeczywistości, dostosowując się do mentalności tego świata, być może wzbudzimy jakąś ludzką sympatię, lecz należy pamiętać, że celem jest przybliżanie do Boga: „Kapłan jest człowiekiem Bożym, tym, który należy do Boga i pobudza

${ }_{62}$ Jan Paweł II, Pastores dabo vobis..., dz. cyt., $\mathrm{nr} 20$. 
do myślenia o Bogu”" ${ }^{63}$. Wiara, cnoty ogólnoludzkie i cnoty chrześcijańskie, wszystko to samo w sobie ma na celu otwarcie dusz na Bożą drogę. Także konieczna zdolność do relacji i współpracy nie ma na celu tego, żeby było nam dobrze razem, ale by mieć łatwiejszy przystęp do Pana, do Jego Osoby, do Jego sposobu postrzegania rzeczywistości, osądzania i życia. Kapłan - przebywając z ludźmi - wie, że prawdziwym celem do osiągnięcia jest doprowadzenie do ich spotkania z Jezusem, wzbudzenie tęsknoty za innym światem, który - choć niewidzialny - nie neguje świata zmysłów, lecz raczej go obejmuje i podnosi. Tęsknoty za światem zamieszkiwanym nie przez bóstwa, których trzeba się bać i których przychylność trzeba sobie zyskać, ale przez Boga, który jest Trójcą, przez Najświętszą Maryję i przez świętych, przez aniołów i szczęśliwe dusze. Chodzimy w Ich towarzystwie, doświadczamy Ich wsparcia, oczekują nas w wiecznej radości. Kościoły, kaplice, przydrożne kapliczki, obrazy ilustrujące naszą wiarę - dają odczuć, że człowiek nie jest sam w swojej ziemskiej pielgrzymce; jest pośrodku wielkiej rzeki, ludu, mającego początek w czasie, a kres w niebie.

6) Pasterska miłość jest „przeżywana w klimacie stałej dyspozycyjności, a wręcz pozwala się "pochłonąć» potrzebom i wymaganiom owczarni. Winny one jednak być sensowne i niekiedy należy dokonywać ich selekcji oraz je weryfikować" ${ }^{64}$. Słowa św. Jana Pawła II okazują się bardzo celne: miłość nie musi popychać pasterza, by zatracił się w innych, w ich wątpliwościach, w ich ciemnościach, skrajnej emocjonalności, w chwiejnym świecie uczuć, w rozumowych sofizmatach. Gdyby tak było, pasterz nie mógłby służyć duszom, wpadłby w pułapkę, byłby niczym sól, która utraciła swój smak.

\section{Krzew gorejący i wieczernik}

Kilka ostatnich słów. Pasterska miłość wymaga uczuciowej dojrzałości: „W dziewictwie i w celibacie czystość zachowuje swoje pierwotne znaczenie ludzkiej płciowości, przeżywanej jako autentyczny przejaw i nieoceniona służba na rzecz miłości w duchu jedności i wzajemnego oddania się osób”65. Zanim jeszcze przywoła się konieczną i spokojną czujność u wrót serca, należy zwrócić

$\begin{array}{ll}63 & \text { Jan Paweł II, Pastores dabo vobis..., dz. cyt., } \mathrm{nr} 47 . \\ 64 & \text { Jan Paweł II, Pastores dabo vobis..., dz. cyt., } \mathrm{nr} 28 . \\ 65 & \text { Jan Paweł II, Pastores dabo vobis..., dz. cyt., } \mathrm{nr} 29 .\end{array}$ 
uwagę na życie duchowe pasterza. Oczywiście charakteryzuje się ono posługą duszpasterską, ale zawsze wychodząc od owego „przebywania z Nim”, pieczętującego powołanie Dwunastu. Najbardziej decydującym kryterium naszego kapłańskiego życia nie jest to, co robimy, lecz to, kim jesteśmy, a zatem jak wypełniamy nasze obowiązki. W prosty sposób można to ująć tak: Czy cieszę się, że jestem kapłanem? Czy czuję wielkość tego, kim Jezus mnie uczynił w chwili święceń? Czy jestem świadom, że czysto ludzkie, bliskie przebywanie z ludźmi nie wystarcza, jeśli nie przybliża dusz do Boga? Czy moja twarz, moje słowa, działania duszpasterskie, prywatne zachowania promieniują tą radością? Jeśli - pomimo codziennych trudów - nie żyjemy głęboką radością, stajemy się introwertyczni, melancholijni i rozżaleni. Idealizujemy położenie innych, oddalając się od rzeczywistości. Wówczas łatwo znajdują się złudne kompensacje, trzyma się z dala od prezbiterium, od życia diecezji, osądzając wszystko ponuro i z nieufnością, uważając wszelkie inicjatywy za niepotrzebne, mało ciekawe i nieodpowiadające własnym preferencjom.

Ludzkie serce nie może żyć bez wewnętrznego ciepła. To się tyczy też nas, pasterzy! Konieczne jest ciągłe zwracanie się do Boga, który wyszedł nam na spotkanie w Chrystusie. To jest sercem każdej odnowy. Nie struktury, organizacje czy programy. Pierwszeństwa Boga nie zapewnia ani wiara w Niego, jeśli się Nim nie żyje, to znaczy jeśli nie żyje się w stałym odniesieniu do Niego, ani praca dla Boga, jeśli się „z” Nim nie pracuje. Rzeczywiście bowiem dzieła Boże mogą sprawić, że zapomnimy, jakie jest Jego oblicze. Aby naprawdę kochać innych i im służyć, musimy pozwolić, aby Jezus nas kochał, w przeciwnym razie ryzykujemy, że w innych ludziach będziemy kochać samych siebie, szukać rekompensaty, przywiązywać się do tych, którzy są nam wdzięczni i wzbudzają naszą sympatię.

Nasze życie duchowe jest przede wszystkim ciągłym powierzaniem się - jak Jezus na krzyżu - Ojcu i Jego woli; jest robieniem miejsca łasce, która nas przemienia $\mathrm{w}$ nowe stworzenia, która daje nam serce $\mathrm{z}$ ciała. Poza tym horyzontem wchodzi się w rozpowszechnioną logikę krypto-pelagiańską, według której w gruncie rzeczy zbawiamy się sami naszą dobrą wolą. Jednak w ten sposób popadamy w desperację niewystarczalności na drodze dobra, serce jest samotne $z$ samym sobą, wewnątrz lodowate - trudno tak żyć. Idzie się wtedy na poszukiwania letnich błędnych ogników.

Wróćmy do prostego słowa Jezusa: „Ustanowił Dwunastu, aby Mu towarzyszyli”. Jeżeli kapłan nie przebywa z Mistrzem, nigdzie nie pójdzie, bo zaniósłby tylko samego siebie. A dusze nie czekają na nas z naszymi zaletami, ale na wielką Nadzieję, wielkie Dobro, wielką Radość. Towarzyszenie Mu oznacza codzienną Mszę, Liturgię Godzin, różaniec, medytację itd. Ale to nie 
wystarcza. Bo powołanie jest „wyznaniem miłości” i jako takie domaga się też intymności, samotności, serca przy sercu. Znaczącym obrazem jest tu „krzew gorejący", przed którym Mojżesz, boso, zatrzymał się w samotności i pozwolił się przemienić. Wydaje mi się, że najbardziej delikatny punkt znajduje się tutaj. Intymność! Wymiar osobisty nie wyklucza wymiaru wspólnotowego, ale go uzasadnia, tak jak wymiar wspólnotowy konkretyzuje osobistą modlitwę.

Braterstwo kapłańskie konieczne jest również dla uczuciowej dojrzałości, o której mówi cytowana adhortacja. Braterstwo przejawiające się w konkretnych formach egzystencji i posługi, ale które najpierw musi karmić człowieczeństwo, wiarę i radość powołania. Musi to być dojrzałe braterstwo. Trzeba bowiem potrafić przebywać $\mathrm{w}$ samotności, aby umieć przebywać $\mathrm{z}$ innymi, i na odwrót. Powodem spotkania ze współbraćmi nie może być coś do zrobienia, ale to, co Jezus uczynił i nadal czyni z każdego z nas, z naszego życia i apostolatu. Spotkanie i przyjaźń prezbiterów muszą nade wszystko pomagać dostrzegać obecność Zmartwychwstałego, aby wspólnie Go wielbić i powierzać Mu owoce posługi, ciesząc się z pracy w Jego winnicy. Wówczas każde spotkanie będzie „wieczernikiem”, gdzie ciepło braterstwa będzie inspirować i dodawać sił.

Drodzy Bracia w kapłaństwie i drodzy Przyjaciele, sekularyzm - wyrafinowana forma totalitaryzmu - jawi się jako „nowy świat”, niczym złoty wiek, czy nareszcie zdobyta ziemia obiecana, wnosząca nowoczesne, wyemancypowane i zadowolone człowieczeństwo. Chrześcijaństwo zaś przeciwnie: przedstawiane jest jako „stary świat”. Jednakże serce człowieka odczuwa tęsknotę za czymś innym, wyższym i szlachetniejszym. Tutaj wkracza Ewangelia, której, dzięki łasce, jesteśmy sługami. Dlatego możemy słusznie powiedzieć, że kapłani nie są ludźmi przeszłości, ale pasterzami przyszłości oraz że wspólnoty chrześcijańskie, ze swoimi problemami, nie chylą się ku zachodowi, lecz promieniują obiecującym światłem wschodzącego słońca. Dziękuję.

(tłum. Kalina Lechowicz) 
Słowa klucze: Jan Paweł, pasterze, aktualność przesłania, sekularyzm a kwestia wiary, pod powierzchnią - życie, kapłańska tożsamość, przebywać z Jezusem, aby móc pójść, powołanie kapłańskie jako „wyznanie miłości”, pasterska miłość, krzew gorejący i wieczernik

Streszczenie: Niezwykle ważna adhortacja apostolska Jana Pawła II Pastores dabo vobis jest dokumentem nadal aktualnym. Przesłanie w niej zawarte, a dotyczące tożsamości kapłańskiej, przebywania z Jezusem ze względu na autentyczne wyznanie miłości, co przekłada się ostatecznie na miłość pasterską, jest mobilizacją do tego, by stawać nieustannie przed Bogiem jak Mojżesz przed krzewem gorejącym oraz doświadczyć jedności wieczernika. Ta tożsamość kapłańska prowadzi też ostatecznie do gorliwości i jakości duszpasterskiej. Przychodzące zaś zagrożenia, jak choćby sekularyzm, jest powodem do pogłębienia wiary przez duchownych. Trafne określenie nadal jest przesłaniem: serce człowieka odczuwa tęsknotę za czymś innym, wyższym i szlachetniejszym. Tutaj wkracza Ewangelia, której dzięki łasce jesteśmy sługami. Dlatego możemy słusznie powiedzieć, że kapłani nie są ludźmi przeszłości, ale pasterzami przyszłości oraz że wspólnoty chrześcijańskie, ze swoimi problemami, nie chylą się ku zachodowi, lecz promieniują obiecującym światłem wschodzącego słońca. Zasada przebywania przed Chrystusem jest ważna dla właściwego promieniowania na powierzonych wiernych.

\section{Pastoral charity as the core of priest's identity and the answer to modern challenges according to Pastores dabo vobis}

Key terms: John Paul II, shepherds, relevance of message, Secularism and the question of faith, under the surface - life, priest's identity, staying with Christ so as to be able to follow, priestly vocation as "declaration of love", pastoral charity, burning bush and cenacle

Abstract: Pastores dabo vobis, the tremendously important apostolic exhortation written by John Paul II is still relevant today. Its message appertaining to a priest's identity and staying with Jesus through the authentic declaration of love, which finally translates into pastoral charity, is the encouragement to stand continually before God, like Moses before the burning bush and to experience the unity of the Cenacle. This priest's identity ultimately leads as well to priest's zeal and quality. The incoming perils, such as secularism give priests more reason to deepen their faith. The following shrewd definition is still a relevant message: man's heart feels longing for something different, higher, nobler. Thus here comes the Gospel which we serve through grace. That is why we can rightly say that priests are not the people of the past, but the shepherds of the future, and that Christian communities, with all their problems, are not leaning towards the west, but are shining with the light of the rising sun. The principle of standing before Christ is vital for shining upon the entrusted faithful. 